Open Access

\title{
Erratum: Concordance and limits between transcutaneous and arterial carbon dioxide pressure in emergency department patients with acute respiratory failure: a single-center, prospective, and observational study
}

Xavier Bobbia ${ }^{1 \dagger}{ }^{1}$, Pierre-Géraud Claret ${ }^{{ }^{*} \dagger}{ }$, Ludovic Palmier ${ }^{1}$, Michaël Robert $^{1}$,

Romain Genre Granpierre ${ }^{1}$, Claire Roger ${ }^{1}$, Justin Yan², Patrick Ray ${ }^{3}$, Mustapha Sebbane ,

Laurent Muller ${ }^{1}$ and Jean-Emmanuel de La Coussaye ${ }^{1}$

\begin{abstract}
After publication of this article (Scand J Trauma Resusc Emerg Med 23:40, 2015), it came to light that an earlier version had been published in error. This erratum contains the correct version of the article, which incorporates revisions made in response to reviewer comments. Additionally, one of the authors was inadvertently omitted from the author list. This author, Justin Yan, has been included in the corrected author list above.

Background: Transcutaneous $\mathrm{CO}_{2}\left(\mathrm{PtCO}_{2}\right)$ is a continuous and non-invasive measure recommended by scientific societies in the management of respiratory distress. The objective of this study was to evaluate the correlation between $\mathrm{PtCO}_{2}$ and arterial partial pressure of $\mathrm{CO}_{2}\left(\mathrm{PaCO}_{2}\right)$ by arterial blood gas analysis in emergency patients with dyspnoea, and to determine the factors that interfere with this correlation.

Methods: From January to June 2014, all adult patients admitted to the RR with dyspnoea during business hours were included in the study if arterial blood gas measurements were indicated. A sensor measuring the $\mathrm{PtCO}_{2}$ was attached to the ear lobe of the patient before the gas analysis. Anamnesis, clinical and laboratory parameters were identified.

Results: Ninety patients with dyspnoea were included (104 pairs of measurements). The median (IQR) age was 79 years $\left(69\right.$ - 85). The correlation between $\mathrm{PtCO}_{2}$ and $\mathrm{PaCO}_{2}$ was $\mathrm{R}^{2}=.83(p<.001)$ but became lower for values of $\mathrm{PaCO}_{2}$ above $60 \mathrm{~mm} \mathrm{Hg}$. The mean bias ( \pm SD) between the two methods of measurement (Bland-Altman analysis) was $-1.4 \mathrm{~mm} \mathrm{Hg}( \pm 7.7)$ with limits of agreement from -16.4 to $13.7 \mathrm{~mm} \mathrm{Hg}$. In univariate analysis, $\mathrm{PaO}_{2}$ interfered with this correlation. After multivariate analysis, temperature $(\mathrm{OR}=3.01 ; 95 \% \mathrm{Cls}[1.16,7.80])$ and $\mathrm{PaO}_{2}(\mathrm{OR}=1.22$; $95 \%$ Cls $[1.02,1.47])$ significantly interfered with this correlation.
\end{abstract}

Conclusions: There is a significant correlation between $\mathrm{PaCO}_{2}$ and $\mathrm{PtCO}_{2}$ values for patients admitted to the emergency department for acute respiratory failure. One limiting factor to routine use of $\mathrm{PtCO}_{2}$ measurements in the emergency department is the presence of hyperthermia.

Keywords: Emergency service, Blood gas monitoring, Transcutaneous, Carbon dioxide, Partial pressure

\footnotetext{
*Correspondence: pierre.geraud.claret@gmail.com

tEqual contributors

1 Pôle Anesthésie Réanimation Douleur Urgences, Nîmes University Hospital, 4

Rue du Professeur Robert Debré 30029 Nîmes, Nîmes, France

Full list of author information is available at the end of the article
} 


\section{Background}

This is a corrected version of the previously published article [1]. Arterial blood gas monitoring is crucial for management of patients with respiratory failure [2]. The gold standard technique involves an arterial puncture which is invasive, time-consuming, and only gives results at one point in time [3, 4]. Moreover, the delay in waiting for the results of blood gas analysis does not allow for real-time adaptation of oxygen therapy or mechanical ventilation. Oxygen saturation by pulse oximetry $\left(\mathrm{SpO}_{2}\right)$ is widely used as a surrogate of arterial oxygen saturation $\left(\mathrm{SaO}_{2}\right)$ [5]. Similarly, end tidal $\mathrm{CO}_{2}\left(\mathrm{EtCO}_{2}\right)$ allows for an indirect, but reliable and continuous assessment of arterial $\mathrm{pCO}_{2}$ for mechanically ventilated patients. However, for non-ventilated patients, assessment of $\mathrm{EtCO}_{2}$ is more complex, less accurate, and often impossible. For these patients, the recently recommended $[6,7]$ transcutaneous monitoring of carbon dioxide $\left(\mathrm{PtCO}_{2}\right)$ could represent an alternative for immediate and continuous assessment of $\mathrm{pCO}_{2}$. Numerous studies of both children $[8,9]$ and adults [10-12] have found a good correlation between $\mathrm{PaCO}_{2}$ and $\mathrm{PtCO}_{2}$. Yet in the specific setting of the emergency department (ED) resuscitation room (RR), $\mathrm{PtCO}_{2}$ has been poorly studied. The main objective of this study was to investigate the relationship between measures of $\mathrm{PtCO}_{2}$ and $\mathrm{PaCO}_{2}$ for patients admitted to the ED RR. The secondary objective was to determine the variables that may disrupt the link between $\mathrm{PtCO}_{2}$ and $\mathrm{PaCO}_{2}$.

\section{Methods}

\section{Setting}

We conducted this single-center prospective observational study from January to June 2014 in the ED of Nîmes University Hospital, France. This study was reviewed and approved by our Institutional Review Board (number: 13/06-02) and was declared to and approved by the national commission for data processing and civil liberties. All patients provided written informed consent. This study is in compliance with the Helsinki Declaration.

\section{Study population}

All adult patients admitted to the RR with dyspnoea during business hours (from 9:00 to 17:00, weekend excluded) were included in the study if arterial blood gas measurements were indicated. In our ED, patients are admitted to the RR if they are level 1 or level 2 according to the Canadian Triage and Acuity Scale (CTAS). Thus, patients with dyspnoea are admitted to the RR if they suffered from severe respiratory distress, asthma, or important dyspnoea. Definition of CTAS level 1 and level 2 for dyspnoea are specified in Appendix 1. Exclusion criteria were incorrect installation of the sensor, signal abnormality on the monitor, and backup error on the memory of the device.

\section{Measurement}

The $\mathrm{PtCO}_{2}$ measurement was performed by a StowSeveringhaus sensor (tc Sensor 92 by Radiometer ${ }^{\mathrm{Tm}}$, Copenhagen, Denmark). The sensor heats skin to a temperature of $44{ }^{\circ} \mathrm{C}$ resulting in a dilatation of the capillary bed that allows for diffusion of gases $\left(\mathrm{CO}_{2}\right.$ and $\mathrm{O}_{2}$ ) [13]. On the sensor, carbon dioxide reacts with water to form carbonic acid which dissociates into $\mathrm{H}^{+}$and $\mathrm{HCO}_{3}^{-}$, thereby changing $\mathrm{pH}$ values. These $\mathrm{pH}$ changes are translated into $\mathrm{PtCO}_{2}$ value through the Henderson-Hasselbalch formula [14]. Medical and paramedical staff were trained in the operation and maintenance of the $\mathrm{PtCO}_{2}$ TOSCA monitor (Radiometer ${ }^{\mathrm{rm}}$, Copenhagen, Denmark) before the study commenced. For included patients, the $\mathrm{PtCO}_{2}$ sensor was attached to the ear lobe of the patient allowing for continuous measurement of $\mathrm{PtCO}_{2}$. After stabilization of the monitor to obtain a good signal, arterial blood gases and $\mathrm{PtCO}_{2}$ measurements were performed simultaneously. The medical team was blinded to the value of $\mathrm{PtCO}_{2}$ measured.

\section{Outcomes}

The primary outcome was concordance between the simultaneous $\mathrm{PaCO}_{2}$ and $\mathrm{PtCO}_{2}$ values. The sample size calculation was based on the anticipated variation in the differences between the measurements and the required precision. Using a previous study [15] for an estimate of the variation between the differences, a sample size of 50 patients gave a precision of $\pm 0.19 \mathrm{kPa}$ as the limits of agreement. The secondary outcome was to determine the factors that interfere with this correlation. $\mathrm{PtCO}_{2}$ values were automatically saved every ten seconds by the monitor. Medical patient data were collected and entered into an electronic database after initial collection on paper case report forms (CRF). Blood pressure, heart rate, respiratory rate, blood oxygen saturation, Glasgow coma scale, temperature, time to completion of arterial blood gases, catecholamine use, and non-invasive ventilation or tracheal intubation were recorded by the attending physician. Characteristics of patients such as ED arrival modalities, hospital length of stay, and biological data were collected on the CRF.

\section{Statistical analysis}

Patient characteristics were described using qualitative (frequencies and percentages) or quantitative variables (means and standard deviations or median with interquartile ranges - depending on type of distribution) where appropriate. The concordance between $\mathrm{PtCO}_{2}$ and $\mathrm{PaCO}_{2}$ was evaluated by linear regression (correlation coefficients) and Bland-Altman analysis, which determined bias, precision, and agreement of $\mathrm{PtCO}_{2}$ and $\mathrm{PaCO}_{2}$, taking the automated analysis in the laboratory as the reference standard. The Pearson correlation 
coefficient was used to demonstrate the presence or absence of a relationship between $\mathrm{PtCO}_{2}$ and $\mathrm{PaCO}_{2}$. Relationships between measurement differences $\left(\mid \mathrm{PaCO}_{2}\right.$ $\mathrm{PtCO}_{2} \mid$ ) and patient characteristics were investigated by regression analysis. Variables related to the difference between $\mathrm{PtCO}_{2}$ and $\mathrm{PaCO}_{2}$ in the univariate analysis (defined by $p<.1$, forward selection) were further analyzed in a multivariate model (analysis of covariance). We included $\mathrm{PaCO}_{2}$ in this model but did not included $\mathrm{pH}$ or $\mathrm{PtCO}_{2}$ to avoid a collinear bias. Overall model fit was assessed using the Hosmer-Lemeshow test. All statistical tests were two sided. A $p$-value less than .05 was considered significant for all analyses.

Analyses were performed with the use of R 3.0.2 (R Core Team 2013, R: A language and environment for statistical computing. R Foundation for Statistical Computing, Vienna, Austria). The authors had full access to and take full responsibility for the integrity of the data.

\section{Results}

Between January 2014 and June 2014, 102 patients were screened for eligibility. Ninety patients were included and analyzed with $104 \mathrm{PtCO}_{2}$ values (Fig. 1). Table 1 shows the patient characteristics corresponding to the 104 measurements. After linear regression analysis of 104 couples of measurements, we found a significant correlation between $\mathrm{PaCO}_{2}$ and $\mathrm{PtCO}_{2}$ with $\mathrm{R}^{2}=.83(p<.001)$ (Fig. 2). The linear regression equation between the two variables was $\mathrm{PaCO}_{2}=\left(0.81 \times \mathrm{PtCO}_{2}\right)+10.86$. The Bland-Altman analysis is shown in Fig. 3. The mean bias was $-1.4 \mathrm{~mm} \mathrm{Hg}$ $( \pm 7.7)$ and the limits of agreement (bias \pm 1.96 SD) between the two techniques were $-16.4 \mathrm{~mm} \mathrm{Hg}$ and $13.7 \mathrm{~mm} \mathrm{Hg}$. The Pearson's correlation coefficient was
.94 (95\% CIs $[0.87,0.94] ; p<.001)$. For the group with $\mathrm{PaC0} 2<60 \mathrm{~mm} \mathrm{Hg}, \mathrm{R}^{2}=.70(p<.001)$ and the mean bias was $-3.5 \mathrm{~mm} \mathrm{Hg}( \pm 5.0)$. For the group with $\mathrm{PaC0} 2>60 \mathrm{~mm} \mathrm{Hg}, \mathrm{R}^{2}=.57(p<.001)$ and the mean bias was $4.1 \mathrm{~mm} \mathrm{Hg}( \pm 10.2)$.

In the univariate analysis, the only factor associated with a difference between $\mathrm{PaCO}_{2}$ and $\mathrm{PtCO}_{2}$ was $\mathrm{PaO}_{2}$ (Table 2). In multivariate analysis with three explanatory variables $\left(\mathrm{PaCO}_{2}, \mathrm{PaO}_{2}\right.$, temperature), we found the temperature and the $\mathrm{PaO}_{2}$ to be significantly associated with a large difference between $\mathrm{PaCO}_{2}$ and $\mathrm{PtCO}_{2}$ (Table 2). The higher the temperature of the patient, the greater the difference between $\mathrm{PaCO}_{2}$ and $\mathrm{PtCO}_{2}$ (Fig. 4). We developed this model on a data set of 93 measurements (11 observations were exluded due to missingness). This model had a non-significant Hosmer-Lemeshow chi-square goodnessof-fit statistic.

\section{Discussion}

To our knowledge, our study is the largest cohort of $\mathrm{PtCO}_{2}$ measurements conducted in the ED. The mean bias was $-1.4 \mathrm{~mm} \mathrm{Hg}( \pm 7.7)$ and the limits of agreement (bias $\pm 1.96 \mathrm{SD}$ ) between the two techniques were -16.4 $\mathrm{mm} \mathrm{Hg}$ and $13.7 \mathrm{~mm} \mathrm{Hg}$. There was a significant correlation between $\mathrm{PaCO}_{2}$ and $\mathrm{PtCO}_{2}\left(\mathrm{R}^{2}=.83 ; p<.001\right)$. Because most of our patients were non-intubated, our results highlight the feasibility and the potential benefit of measuring PtCO2 since EtCO2 cannot easily be monitored in non-intubated patients. The correlation coefficient in our study was comparable to what was shown in a previous intensive care study $\left(\mathrm{R}^{2}=.86 ; p<.01\right)[10]$. However, other studies have found a stronger correlation ( $\mathrm{R}^{2}$ coefficient, ranged between .91 and .99 [16-18]).

102 patients enrolled (dyspnoea + CTAS 1/2)

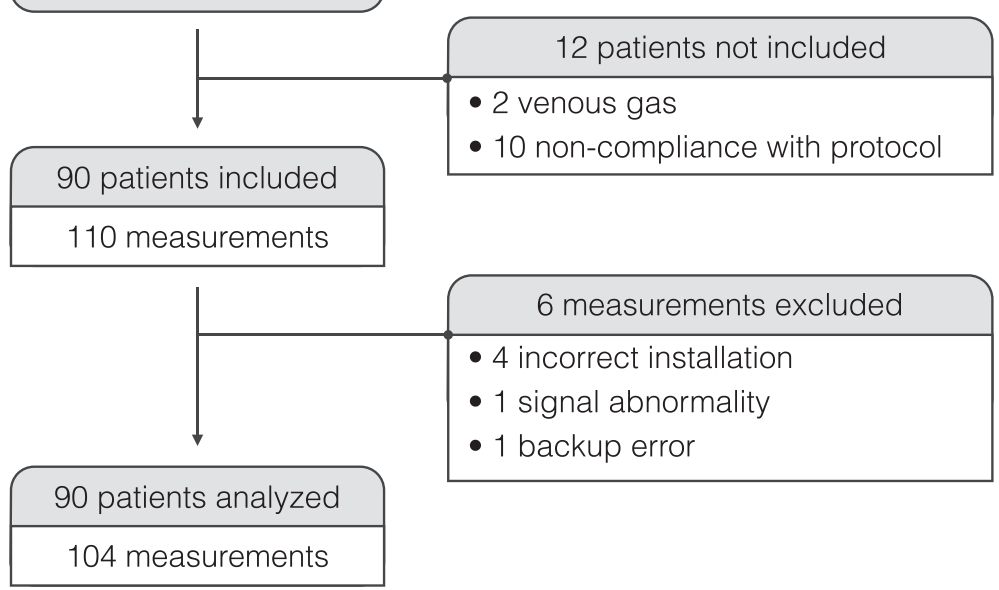

Fig. 1 Flow diagram 
Table 1 Patients' characteristics

\begin{tabular}{|c|c|}
\hline Male sex, no. (\%) & $51(57)$ \\
\hline Age, mean $( \pm S D)$ - year & $76(15)$ \\
\hline \multicolumn{2}{|l|}{ Past medical history, no. (\%) } \\
\hline Acute pulmonary edema & $27(29)$ \\
\hline Chronic obstructive pulmonary disease & $27(29)$ \\
\hline Ischemic heart disease & $21(23)$ \\
\hline Home oxygen & $16(17)$ \\
\hline \multicolumn{2}{|l|}{ Clinical data at admission, median (IQR) } \\
\hline Heart rate - beats/min. & $94(80-110)$ \\
\hline Systolic blood pressure - mm Hg & $122(106-144)$ \\
\hline Diastolic blood pressure - mm Hg & $69(60-78)$ \\
\hline Respiratory rate - breaths/min. & $24(19-28)$ \\
\hline Glasgow coma scale & $15(14-15)$ \\
\hline Temperature $-{ }^{\circ} \mathrm{C}$ & $37.0(36.2-37.6)$ \\
\hline \multicolumn{2}{|l|}{ Laboratory values, median (IQR) } \\
\hline $\mathrm{PaCO}_{2}-\mathrm{mm} \mathrm{Hg}$ & $46.2(37.6-66.8)$ \\
\hline $\mathrm{PtCO}_{2}-\mathrm{mm} \mathrm{Hg}$ & $47.2(42.1-60.0)$ \\
\hline $\mathrm{PaO}_{2}-\mathrm{mm} \mathrm{Hg}$ & $73.5(63.0-89.0)$ \\
\hline $\mathrm{pH}$ & $7.37(7.30-7.43)$ \\
\hline $\mathrm{HCO}_{3}-\mathrm{mEq} / \mathrm{L}$ & $26.0(22.8-29.7)$ \\
\hline Base excess - mmol/L & $1.9(-1.9-5.8)$ \\
\hline Lactate - mmol/L & $1.3(0.7-2.2)$ \\
\hline Hemoglobin - g/dL & $12.3(10.9-13.8)$ \\
\hline White blood cells - G/L & $12.4(7.9-15.5)$ \\
\hline C-reactive protein & $41(8-122)$ \\
\hline Glycemia - g/L & $1.4(1.2-1.7)$ \\
\hline Brain natriuretic peptide - ng/L & $1704(579-6200)$ \\
\hline \multicolumn{2}{|l|}{ Diagnosis, no. (\%) } \\
\hline Heart failure & $25(27)$ \\
\hline COPD & $14(15)$ \\
\hline Pneumonia & $42(46)$ \\
\hline Pulmonary embolism & $5(5)$ \\
\hline \multicolumn{2}{|l|}{ Outcome, no. (\%) } \\
\hline Noninvasive ventilation required & $41(45)$ \\
\hline Intubation required & $4(4)$ \\
\hline Admitted to hospital & $61(66)$ \\
\hline Admitted to ICU & $19(21)$ \\
\hline Discharged from ED & $10(11)$ \\
\hline Death at the ED & $2(2)$ \\
\hline Inpatient mortality & $9(10)$ \\
\hline
\end{tabular}

We assume this difference is not a consequence of the use of various devices since most of the studies were completed with a Radiometer ${ }^{\text {mit }}$ device. This difference can be explained by the selection of our patients, as only those in the RR with acute respiratory failure were included.

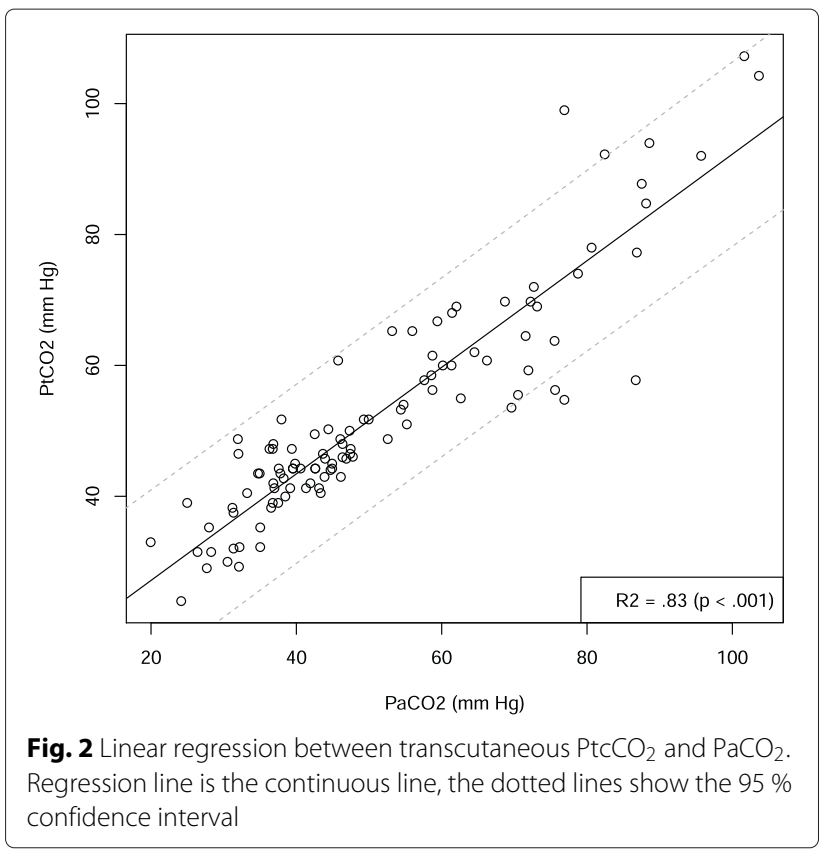

Indeed, the high and extreme $\mathrm{PaCO}_{2}$ values were reported as possibly interfering with the correlation between $\mathrm{PtCO}_{2}$ and $\mathrm{PaCO}_{2}[10,19-21]$. In a study by Delerme et al. [11], patients had a lower $\mathrm{PaCO} 2$ than in our study (39 $\mathrm{mm} \mathrm{Hg}$ vs. 46, respectively). Secondly, this difference may result from the use of the device by many physicians. Calibration, sensor placement and latency to reach the plateau value of $\mathrm{PtCO}_{2}$ may differ from one physician to another. Because some operators used the monitor less frequently, this may have led to poorer reproducibility. However, it also reflects our center's daily practice and

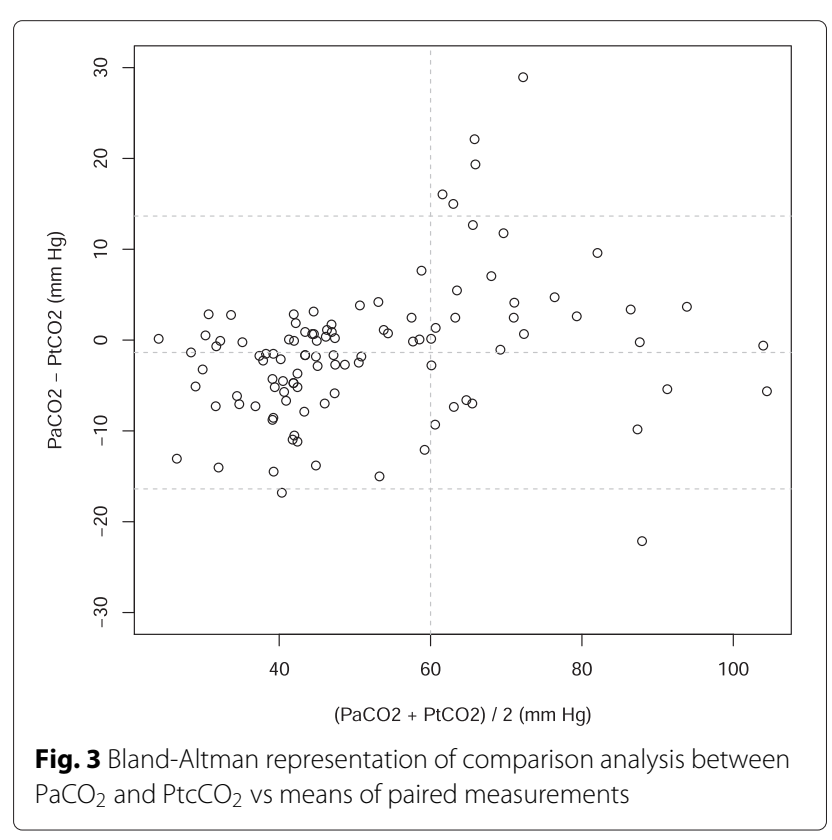


Table 2 Relationships between measurement differences (|PaCO2-PtCO2|) and patient characteristics using univariate and multivariate analysis (ANCOVA)

\begin{tabular}{|c|c|c|c|c|}
\hline \multirow[b]{2}{*}{ Variable } & \multicolumn{2}{|c|}{ Univariate analysis } & \multicolumn{2}{|c|}{ Multivariate analysis } \\
\hline & OR [95 \% Cls] & $P$-value & OR [95 \% Cls] & $P$-value \\
\hline Sex & $1.61[0.18,14.25]$ & .66 & & \\
\hline \multicolumn{5}{|l|}{ Past medical history } \\
\hline $\begin{array}{l}\text { Acute pulmonary } \\
\text { edema }\end{array}$ & $0.29[0.03,2.96]$ & .29 & & \\
\hline COPD & $0.60[0.06,6.18]$ & .67 & & \\
\hline $\begin{array}{l}\text { Ischemic heart } \\
\text { disease }\end{array}$ & $0.75[0.06,8.91]$ & .82 & & \\
\hline Home oxygen & $1.01[0.06,16.77]$ & .99 & & \\
\hline Heart rate & $0.98[0.94,1.03]$ & .40 & & \\
\hline $\begin{array}{l}\text { Systolic blood } \\
\text { pressure }\end{array}$ & $1.01[0.97,1.05]$ & .60 & & \\
\hline $\begin{array}{l}\text { Diastolic blood } \\
\text { pressure }\end{array}$ & $0.97[0.91,1.03]$ & .33 & & \\
\hline Respiratory rate & $1.01[0.88,1.18]$ & .85 & & \\
\hline Temperature & $2.45[0.93,6.49]$ & .07 & $3.01[1.16,7.80]$ & .03 \\
\hline $\mathrm{PaCO}_{2}$ & $1.05[1.00,1.12]$ & .06 & $1.06[1.00,1.12]$ & .05 \\
\hline $\mathrm{PtCO}_{2}$ & $1.06[1.00,1.13]$ & .06 & & \\
\hline $\mathrm{PaO}_{2}$ & $1.21[1.01,1.45]$ & .04 & $1.22[1.02,1.47]$ & .03 \\
\hline $\mathrm{HCO}_{3}$ & $0.96[0.80,1.15]$ & .64 & & \\
\hline Base excess & $0.96[0.82,1.12]$ & .60 & & \\
\hline Lactate & $1.44[0.43,4.79]$ & .54 & & \\
\hline Hemoglobin & $1.20[0.74,1.95]$ & .45 & & \\
\hline White blood cells & $0.91[0.74,1.12]$ & .38 & & \\
\hline C-reactive protein & $1.00[0.99,1.01]$ & .72 & & \\
\hline Glycemia & $4.70[0.62,35.58]$ & .13 & & \\
\hline $\begin{array}{l}\text { Brain natriuretic } \\
\text { vpeptide }\end{array}$ & $1.00[1.00,1.00]$ & .82 & & \\
\hline
\end{tabular}

this issue may occur with any change of device. Thirdly, we did not correct the arterial blood gases according to the patient's temperature and this may explain a portion of the increased difference. Finally, our population was more likely to have significant dyspnoea and therefore agitation or diaphoresis leading to movement of the sensor may have led to inaccurate measurements. Indeed, in the Gancel et al. study [12] where the difference was lower, the exclusion criteria were very rigorous. Authors did not study patients with status epilepticus, confusion or agitation. According to the authors, these criteria may have led to the exclusion of some patients with severe hypercapnia.

Our study found that $\mathrm{PtCO}_{2}$ values were generally greater than $\mathrm{PaCO}_{2}$ values. Indeed, our linear regression equation is $\mathrm{PaCO}_{2}=\left(0.81 \times \mathrm{PtCO}_{2}\right)+10.86$. This overestimation is in accordance with available literature

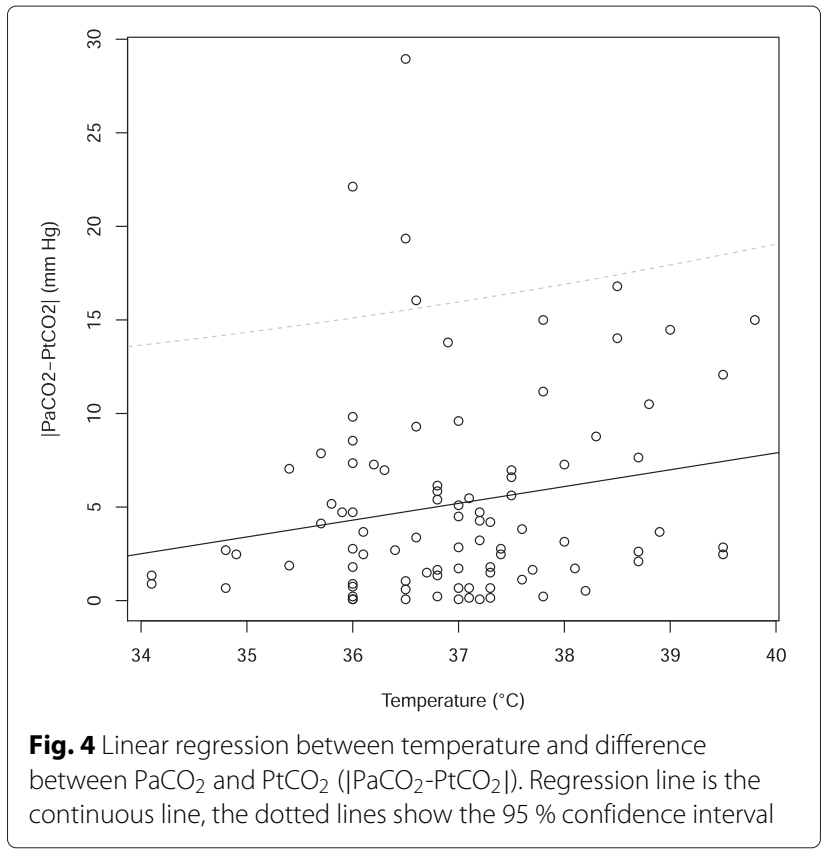

$[10,22,23]$ and may have implications for patients requiring non-invasive ventilation and with no arterial blood gas reference. Thus, the recommendations highlight the need to conduct an arterial blood gas analysis to support the correlation between $\mathrm{PaCO}_{2}$ and $\mathrm{PtCO}_{2}$ values [6]. This issue is important given that the Bland-Altman analysis reveals a poorer correlation for $\mathrm{PtCO}_{2}$ values above $60 \mathrm{~mm} \mathrm{Hg}$. The value of the mean bias reported in our study corresponds to those found in the literature $(-1.4$ to $4.6 \mathrm{~mm} \mathrm{Hg})[16,24,25]$. The decrease of the correlation for high $\mathrm{PaCO}_{2}$ values has been previously reported. The accuracy of $\mathrm{PtCO}_{2}$ seems to be better for patients with $\mathrm{PaCO}_{2}$ values below $56 \mathrm{~mm} \mathrm{Hg}$ [26]. One explanation for this poor correlation is that the clinical manifestations of hypercapnia (excessive sweating and vasodilatation) leads to a lower diffusion of carbon dioxide [26]. In our study, after multivariate analysis, temperature was associated with a poor correlation between $\mathrm{PaCO}_{2}$ and $\mathrm{PtCO}_{2}(\mathrm{OR}=3.01 ; 95 \%$ CIs $[1.16,7.80] ; p=.03)$. The issue that the temperature can influence the correlation has been raised by Rodriguez et al. [27]. Our linear regression analysis revealed that the higher the body temperature, the greater the difference between $\mathrm{PaCO}_{2}$ and $\mathrm{PtCO}_{2}$ values. This poor correlation can be explained by the fact that asthe patient's temperature increased, the difference between the patient and the temperature sensor $\left(44{ }^{\circ} \mathrm{C}\right)$ decreased, resulting in small changes in local perfusion and production of $\mathrm{CO}_{2}$. This hypothesis follows directly from the operating principle of the sensor [6]. It could also be hypothesized that a high body temperature promotes sweating and vasodilatation making the sensor's 
measurement more inaccurate. Finally, a low blood pressure could also be a cause of a poor correlation between $\mathrm{PaCO}_{2}$ and $\mathrm{PtCO}_{2}$ [28]. Unfortunately, this hypothesis cannot be confirmed by our data because few patients had shock criteria. Similarly, the assumption that the $\mathrm{pH}$ may explain a poor correlation [21] cannot not be confirmed in our study with the multivariate analysis.

\section{Limitations}

Although several studies have found a poor correlation between $\mathrm{PaCO}_{2}$ and $\mathrm{PtCO}_{2}$ in patients with shock who are treated with catecholamines [10], we did not analyze this particular relationship. Indeed, we included few patients with hemodynamic instability requiring the administration of intravenous fluids or vasopressor support. It is therefore difficult to assess the impact of decreased circulation on the correlation between $\mathrm{PaCO}_{2}$ and $\mathrm{PtCO}_{2}$. Several studies have shown that the correlation is not affected by catecholamines but by dermal vasoconstriction secondary to a state of shock [23, 27].

Secondly, body mass index (BMI) was not measured in our study. Several studies reported conflicting conclusions regarding the influence of skin thickness, indirectly estimated by BMI, on the $\mathrm{CO}_{2}$ diffusion to the skin and therefore on the $\mathrm{PaCO}_{2}$ values $[10,23,25,26]$. However, there is no correlation between BMI and the skin on the earlobe, where the sensor was fixed [29].

Finally, one subject that remains to be explored is the intra-individual correlation. Most of the patients had only one arterial blood gas measurement during their management in the RR, which was inadequate for obtaining intra-individual correlations between different $\mathrm{PtCO}_{2}$ and $\mathrm{PaCO}_{2}$ values. This analysis would be important to predict $\mathrm{PaCO}_{2}$ values from continuous measurement of $\mathrm{PtCO}_{2}$, especially for patients requiring several hours of monitoring $[27,30]$.

\section{Conclusions}

There is a significant correlation between $\mathrm{PaCO}_{2}$ and $\mathrm{PtCO}_{2}$ values for patients admitted to the ED for acute respiratory failure. This correlation is particularly accurate for values below $60 \mathrm{~mm} \mathrm{Hg}$. One limiting factor to routine use of $\mathrm{PtCO}_{2}$ measurements in the ED is the presence of hyperthermia.

\section{Key messages}

- There is a significant correlation between $\mathrm{PaCO}_{2}$ and $\mathrm{PtCO}_{2}$ values for patients admitted to the emergency department for acute respiratory failure.

- This correlation is comparable to that which has been shown in intensive care.

- One limiting factor to the use of $\mathrm{PtCO}_{2}$ measurements in the ED is the presence of hyperthermia.

\section{Appendix 1: Definition of Canadian triage and acuity scale (CTAS) level $\mathbf{1}$ and level $\mathbf{2}$ for dyspnoea Patients with dyspnoea and CTAS Level 1:}

Severe respiratory distress: serious intracranial events, pneumothorax, near death asthma (unable to speak, cyanosis, lethargic/confused, tachycardia/bradycardia, arterial oxygen saturation below $90 \%$ ), chronic obstructive pulmonary disease exacerbations, cardiac heart failure, anaphylaxis and severe metabolic disturbances (renal failure, diabetic keto-acidosis).

\section{Patients with dyspnoea and CTAS Level 2:}

Asthma: severe asthma defined with a combination of objectives measures and clinical factors which relate to the severity of symptoms, vital signs and history of previous severe episodes. If the forced expiratory volume in $1 \mathrm{sec}-$ ond or peak expiratory flow rate are below $40 \%$ predicted or previous best, the patient is considered severe.

Dyspnea: this is subjective and may correlate poorly with lung function or deficits in oxygen uptake and delivery. Depending on the age, previous history and physical assessment one may not be able to distinguish between asthma chronic obstructive pulmonary disease, cardiac heart failure, pulmonary embolism, pneumothorax, pneumonia, croup, epiglottitis, anaphylaxis or a combination of problems.

\section{Abbreviations \\ ANCOVA: Analysis of covariance; BMI: Body mass index; Cl: Confidence interval; CTAS: Canadian triage and acuity scale; COPD: Chronic obstructive pulmonary disease; CRF: Case report form; ED: Emergency department; $\mathrm{EtCO}_{2}$ : End tidal $\mathrm{CO}_{2}$; ICU: Intensive care unit; IQR: Interquartile range; OR: Odds ratio; RR: Resuscitation room; $\mathrm{PaCO}_{2}$ : Partial pressure of carbon dioxide in the blood; $\mathrm{PtCO}_{2}$ : Transcutaneous partial pressure of carbon dioxide in the blood; $\mathrm{PaO}_{2}$ : Partial pressure of dioxygen in the blood; $\mathrm{SaO}_{2}$ : Arterial oxygen saturation; $\mathrm{SpO}_{2}$ : Oxygen saturation by pulse oxymetry.}

Competing interests

The authors declare that they have no competing interests.

\section{Authors' contributions}

$X B, P G C, L P$ and MR conceived the study and wrote the manuscript. JEdLC was the director of this research project and participated to the writing of this manuscript. LP and MR performed the exams. PGC was the responsible of the statistical analysis. XB, PGC, LP, MR, RGG, CR, JY, PR, MS, LM and JEdLC have been involved in drafting the manuscript or revising it critically for important intellectual content. XB, PGC, LP, MR, RGG, CR, JY, PR, MS, LM and JEdLC have given final approval of the version to be published and agree to be accountable for all aspects of the work in ensuring that questions related to the accuracy or integrity of any part of the work are appropriately investigated and resolved.

\section{Authors' information}

Xavier Bobbia and Pierre-Géraud Claret have contributed equally and are both first authors.

\section{Acknowledgements}

The authors acknowledge all the emergency physicians at Nîmes University Hospital who recruited the patients, the residents who helped in this process, and other members of our research team for their help. 


\section{Author details}

'Pôle Anesthésie Réanimation Douleur Urgences, Nîmes University Hospital, 4 Rue du Professeur Robert Debré 30029 Nîmes, Nîmes, France. ${ }^{2}$ Division of Emergency Medicine, Department of Medicine, London Health Sciences Centre and The Schulich School of Medicine and Dentistry, The University of Western Ontario, London, Ontario, Canada. ${ }^{3}$ Emergency Department, Hôpital Tenon, Assistance Publique - Hôpitaux de Paris, 4 Rue de la Chine 75020 Paris, Paris, France.

\section{Received: 7 September 2015 Accepted: 7 September 2015}

Published online: 06 October 2015

\section{References}

1. Bobbia X, Claret PG, Palmier L, Robert M, Grandpierre RG, Roger C, et al. Concordance and limits between transcutaneous and arterial carbon dioxide pressure in emergency department patients with acute respiratory failure: a single-center prospective observational study. Scand J Trauma Resusc Emerg Med. 2015;23:40.

2. Rady MY. Bench-to-bedside review: Resuscitation in the emergency department. Crit Care. 2005 Apr;9(2):170-6

3. Burri E, Potocki M, Drexler B, Schuetz P, Mebazaa A, Ahlfeld U, et al. Value of arterial blood gas analysis in patients with acute dyspnea: an observational study. Crit Care. 2011;15(3):R145.

4. Bobbia X, Grandpierre RG, Claret PG, Moreau A, Pommet S, Bonnec JM, et al. Ultrasound guidance for radial arterial puncture: a randomized controlled trial. Am J Emerg Med. 2013 May;31(5):810-5.

5. Silversides JA, Ferguson ND. Clinical review: Acute respiratory distress syndrome - clinical ventilator management and adjunct therapy. Crit Care. 2013;17(2):225.

6. Restrepo RD, Hirst KR, Wittnebel L, Wettstein R. AARC clinical practice guideline: transcutaneous monitoring of carbon dioxide and oxygen: 2012. Respir Care. 2012 Nov;57(11):1955-62.

7. Brochard L, Martin GS, Blanch L, Pelosi P, Belda FJ, Jubran A, et al. Clinical review: Respiratory monitoring in the ICU - a consensus of 16. Crit Care. 2012;16(2):219.

8. Monaco F, Nickerson BG, McQuitty JC. Continuous transcutaneous oxygen and carbon dioxide monitoring in the pediatric ICU. Crit Care Med. 1982 Nov;10(11):765-6.

9. O'Connor TA, Grueber R. Transcutaneous measurement of carbon dioxide tension during long-distance transport of neonates receiving mechanical ventilation. Perinatol. 1998;18(3):189-92.

10. Bendjelid K, Schütz N, Stotz M, Gerard I, Suter PM, Romand JA. Transcutaneous PCO2 monitoring in critically ill adults: clinical evaluation of a new sensor. Crit Care Med. 2005 Oct;33(10):2203-6.

11. Delerme S, Montout V, Goulet H, Arhan A, Le Saché F, Devilliers C, et al. Concordance between transcutaneous and arterial measurements of carbon dioxide in an ED. Am J Emerg Med. 2012 Nov;30(9):1872-6.

12. Gancel PE, Roupie E, Guittet L, Laplume S, Terzi N. Accuracy of a transcutaneous carbon dioxide pressure monitoring device in emergency room patients with acute respiratory failure. Intensive Care Med. 2011 Feb;37(2):348-51.

13. Severinghaus JW, Astrup P, Murray JF. Blood gas analysis and critical care medicine. Am J Respir Crit Care Med. 1998 Apr;157(4 Pt 2):S114-22.

14. Kellum JA. Determinants of blood pH in health and disease. Crit Care. 2000;4(1):6-14.

15. Heuss LT, Chhajed PN, Schnieper P, Hirt T, Beglinger C. Combined pulse oximetry/cutaneous carbon dioxide tension monitoring during colonoscopies: pilot study with a smart ear clip. Digestion. 2004;70(3): 152-8.

16. Storre JH, Steurer B, Kabitz HJ, Dreher M, Windisch W. Transcutaneous PCO2 monitoring during initiation of noninvasive ventilation. Chest. 2007 Dec;132(6):1810-6.

17. McVicar J, Eager R. Validation study of a transcutaneous carbon dioxide monitor in patients in the emergency department. Emerg Med J. 2009 May;26(5):344-6.

18. Cox M, Kemp R, Anwar S, Athey V, Aung T, Moloney ED. Non-invasive monitoring of CO2 levels in patients using NIV for AECOPD. Thorax. 2006 Apr;61(4):363-4.

19. McLellan PA, Goldstein RS, Ramcharan V, Rebuck AS. Transcutaneous carbon dioxide monitoring. Am Rev Respir Dis. 1981 Aug;124(2):199-201.
20. Tobias JD. Transcutaneous carbon dioxide monitoring in infants and children. Paediatr Anaesth. 2009 May;19(5):434-44.

21. Versmold HT, Linderkamp O, Holzmann M, Strohhacker I, Riegel K. Transcutaneous monitoring of PO2 in newborn infants: where are the limits? Influence of blood pressure, blood volume, blood flow, viscosity, and acid base state. Birth Defects Orig Artic Ser. 1979;15(4):285-94.

22. Rosner V, Hannhart B, Chabot F, Polu JM. Validity of transcutaneous oxygen/carbon dioxide pressure measurement in the monitoring of mechanical ventilation in stable chronic respiratory failure. Eur Respir J. 1999 May;13(5):1044-7.

23. Janssens JP, Howarth-Frey C, Chevrolet JC, Abajo B, Rochat T. Transcutaneous PCO2 to monitor noninvasive mechanical ventilation in adults: assessment of a new transcutaneous PCO2 device. Chest. 1998 Mar;113(3):768-73.

24. Lang CJ. Apnea testing guided by continuous transcutaneous monitoring of partial pressure of carbon dioxide. Crit Care Med. 1998 May;26(5): 868-72.

25. Maniscalco M, Zedda A, Faraone S, Carratù P, Sofia M. Evaluation of a transcutaneous carbon dioxide monitor in severe obesity. Intensive Care Med. 2008 Jul;34(7):1340-4.

26. Cuvelier A, Grigoriu B, Molano LC, Muir JF. Limitations of transcutaneous carbon dioxide measurements for assessing long-term mechanical ventilation. Chest. 2005 May;127(5):1744-8.

27. Rodriguez P, Lellouche F, Aboab J, Buisson CB, Brochard L. Transcutaneous arterial carbon dioxide pressure monitoring in critically ill adult patients. Intensive Care Med. 2006 Feb;32(2):309-12.

28. Belenkiy S, Ivey KM, Batchinsky Al, Langer T, Necsoiu C, Baker W, et al. Noninvasive carbon dioxide monitoring in a porcine model of acute lung injury due to smoke inhalation and burns. Shock. 2013 Jun;39(6):495-500.

29. Edston E. The earlobe crease, coronary artery disease, and sudden cardiac death: an autopsy study of 520 individuals. Am J Forensic Med Pathol. 2006 Jun;27(2):129-33.

30. Randerath WJ, Stieglitz S, Galetke W, Anduleit N, Treml M, Schäfer T. Evaluation of a system for transcutaneous long-term capnometry. Respiration. 2010;80(2):139-45.

\section{Submit your next manuscript to BioMed Central and take full advantage of:}

- Convenient online submission

- Thorough peer review

- No space constraints or color figure charges

- Immediate publication on acceptance

- Inclusion in PubMed, CAS, Scopus and Google Scholar

- Research which is freely available for redistribution

Submit your manuscript at www.biomedcentral.com/submit
C Biomed Central 